\title{
HUBUNGAN ANTARA STATUS GIZI DENGAN USIA MENARCHE PADA REMAJA PUTRI DI DESA BRAJAN MOJOSONGO BOYOLALI
}

\author{
Oleh : \\ Sri Aminingsih ${ }^{1}$, Kharisma Ayu Susilowati ${ }^{2}$, Ichlasi Lintang Suminar ${ }^{3}$
}

\begin{abstract}
Introduction: Based on the results of a survey conducted on 3 while young women who have not experienced menarche at Brajan village district of Mojosongo Boyolali, one of which weighed $34 \mathrm{~kg}$ and height $130 \mathrm{~cm}$ so that her BMI 20.12 included in the normal BMl classification, while one young woman has severe weight $25 \mathrm{~kg}$ and height $120 \mathrm{~cm}$ so that her BMl 17.36, and 1 teenage daughter weighing $34 \mathrm{~kg}$ and height $137 \mathrm{~cm}$ so that her BMI 18.08. Both BMI calculation results of these two young women were categorized as underweight light.

The Purpose: To determine the relationship between nutritional status and age of menarche in young women in the Brajan village district of Mojosongo Boyolali.

Method: Cross-sectional study.

Subjects: The research subjects are 21 girls who are experiencing menarche 10-14 years old. The study was conducted by assessing the results of the IMT. Data were analyzed with Chi Square test.

The Results: Average rate age of menarche occurred at the age of 12.5 years and had normal nutritional status. Results chi squere $p=0.653$ which means that $p>0.05$.

Conclusion: There is no relationship between nutritional status and age of menarche in adolescent girls at Brajan village district of Mojosongo Boyolali.
\end{abstract}

Keywords: menarche, adolescent girls and nutritional status

\section{PENDAHULUAN}

Masa remaja adalah fase pertumbuhan dan perkembangan saat individu mencapai usia 10-19 tahun. Dalam rentang waktu ini terjadi pertumbuhan fisik yang cepat, termasuk pertumbuhan serta kematangan dari fungsi organ reproduksi. (Tarwoto, et al., 2012) Perubahan dari masa kanak-kanak menuju masa remaja atau sering dikenal dengan istilah masa pubertas ditandai dengan datangnya haid pertama (menarche) pada wanita atau mimpi basah pada pria. Datangnya haid ini tidak sama pada setiap wanita. Banyak faktor yang menyebabkan perbedaan tersebut, beberapa diantaranya adalah karena gizi, hormonal, psikologis lingkungan, dan lain-lain. Pubertas pada wanita memang tampak lebih kompleks dibandingkan yang dialami pria. Terkadang ada seorang wanita remaja yang mendapatkan haid pertama (menarche) di usia 8 tahun, namun ada pula yang pada usia 12 tahun, bahkan 16 tahun. (Lestari, 2011)

Usia haid pertama pada tiap remaja sangat bervariasi dan lebih berkorelasi dengan maturasi tulang di banding umur kronologik. Di Indonesia dan negara-negara Asia Tenggara, seorang wanita remaja mendapat menarche rata-rata pada usia 12 tahun. Meskipun ada juga yang baru berusia 8 tahun sudah memulai siklusnya, jumlah usia ini sedikit sekali. Usia paling lama 
mendapat menarche adalah 16 tahun. Dengan demikian, dapat disimpulkan bahwa usia saat seorang wanita mulai mendapat menarche tidak pasti atau bervariasi. Akan tetapi, terdapat kecenderungan bahwa dari tahun ke tahun wanita mendapat haid pertama pada usia yang lebih muda. (Lestari, 2011) Usia gadis remaja pada waktu pertama kalinya mendapat haid (menarche) bervariasi lebar, yaitu 10-16 tahun, tetapi rata-ratanya 12,5 tahun. Statistik menunjukkan bahwa usia menarche dipengaruhi faktor keturunan, keadaan gizi, dan kesehatan umum. Semmelweiss menyatakan bahwa 100 tahun yang lampau usia gadis-gadis Vienna pada waktu menarche berkisar antara 15-19 tahun. Menurut Brown menurunnya usia waktu menarche itu sekarang disebabkan oleh keadaan gizi dan kesehatan umum yang membaik, dan berkurangnya penyakit menahun. Menarche terjadi di tengah-tengah masa pubertas, yaitu masa peralihan dari anak anak-anak ke dewasa. (Wiknjosastro, Saifuddin, dan Rachimhadhi, ed., 2005)

Berdasarkan hasil survei sementara yang dilakukan pada 3 dari 33 remaja putri yang belum mengalami menarche di Desa Brajan Mojosongo Boyolali, 1 diantaranya memiliki berat badan $34 \mathrm{~kg}$ dan tinggi badan $130 \mathrm{~cm}$ sehingga IMT nya 20,12 termasuk dalam klasifikasi IMT normal, sedangkan 1 remaja putri memiliki berat badan $25 \mathrm{~kg}$ dan tinggi badan $120 \mathrm{~cm}$ sehingga IMT nya 17,36 , dan 1 remaja putri memiliki berat badan $34 \mathrm{~kg}$ dan tinggi badan $137 \mathrm{~cm}$ sehingga IMT nya 18,08. Kedua hasil penghitungan IMT dari dua remaja putri tersebut termasuk dalam klasifikasi kekurangan berat badan ringan.

\section{TUJUAN}

Secara umum penelitian ini bertujuan untuk mengetahui hubungan antara status gizi dengan usia menarche pada remaja putri di Desa Brajan Mojosongo Boyolali.

\section{DESAIN PENELITIAN}

Pada penelitian ini penulis menggunakan desain penelitian korelasi dengan pendekatan metode cross sectional untuk mengetahui hubungan status gizi sebagai variabel bebas dan usia menarche sebagai variabel terikat.

Korelasi adalah penelitian yang bertujuan mengetahui hubungan korelatif antarvariabel dengan melibatkan minimal dua variabel. Sedangkan cross sectional merupakan rancangan penelitian yang pengukuran atau pengamatannya dilakukan secara simultan pada satu (sekali waktu). (Hidayat, 2008)

Populasi merupakan seluruh subjek atau objek dengan karakteristik tertentu yang akan diteliti. Bukan hanya objek atau subjek yang dipelajari saja tetapi seluruh karakteristik atau sifat yang dimiliki subjek atau objek tersebut. (Hidayat, 2008) Populasi dalam penelitian ini adalah semua remaja putri berusia 8-16 tahun yang baru saja mendapatkan menstruasi pertama di Desa Brajan Mojosongo Boyolali. Pengambilan sampel dalam penelitian ini adalah dengan teknik consecutive sampling, yaitu cara pengambilan sampel dilakukan dengan memilih sampel yang memenuhi kriteria penelitian sampai kurun waktu tertentu yaitu selama 3 bulan sehingga jumlah sampel terpenuhi. Dalam melakukan pengumpulan data pada penelitian ini, peneliti menggunakan alat ukur berupa timbangan berat badan, pengukur tinggi badan, dan penghitungan IMT untuk variabel status gizi, sedangkan untuk variabel 
usia menarche menggunakan teknik wawancara. Tingkat kepercayaan untuk penelitian ini adalah $p=0,05$ atau $5 \%$ dengan memakai rumus chi kuadrat artinya bahwa tingkat kepercayaan 95\%, atau tingkat kesalahan $5 \%$.

\section{HASIL PENELITIAN}

Berdasarkan penelitian yang telah dilakukan dari bulan November 2014 - Februari 2015 didapatkan hasil sebagai berikut :

Tabel 1. Distribusi frekuensi status gizi

\begin{tabular}{ccc}
\hline Status Gizi & $\mathrm{f}$ & $\%$ \\
\hline Kurang & 6 & 28,6 \\
\hline Normal & 12 & 57,1 \\
\hline Lebih & 3 & 14,3 \\
\hline Total & 21 & 100 \\
\hline
\end{tabular}

Dari tabel di atas dapat dicermati bahwa persentase pada status gizi dengan kategori kurang berjumlah 6 responden $(28,6 \%)$, status gizi normal berjumlah 12 responden $(57,1 \%)$ dan status gizi lebih berjumlah 3 responden (14,3\%).

Table 2. Distribusi frekuensi usia

\begin{tabular}{ccc}
\multicolumn{3}{c}{ menarche } \\
\hline Kelompok Umur & $f$ & $\%$ \\
\hline $8-10$ & 1 & 4,8 \\
\hline $11-13$ & 17 & 81,0 \\
\hline $14-16$ & 3 & 14,3 \\
\hline Total & 21 & 100 \\
\hline
\end{tabular}

Dari tabel di atas diperoleh informasi bahwa responden dengan kelompok umur 8-10 tahun berjumlah 1 responden $(4,8 \%)$, kelompok umur 11-13 tahun berjumlah 17 responden $(81,0 \%)$ dan kelompok umur 14-16 berjumlah 3 responden (14,3\%).

Dari hasil uji Chi-Square program SPSS versi 16.0 dengan $\alpha=5 \%$ (0.05) diperoleh $\mathrm{p}$ sebesar 0,653 sehingga nilai $p>0.05$, yang berarti $\mathrm{Ha}$ ditolak dan $\mathrm{H}_{\mathrm{o}}$ diterima, sehingga tidak ada hubungan status gizi dengan usia menarche pada remaja putri di Desa Brajan Mojosongo Boyolali.

\section{PEMBAHASAN}

1. Status gizi

Dari hasil tabel status gizi dapat dicermati bahwa persentase pada kategori status gizi yang paling tinggi adalah normal dengan jumlah 12 responden (57,1\%), dan status gizi paling rendah adalah kategori gizi lebih yang berjumlah 3 responden (14,3\%). Hasil dari data tersebut bisa disimpulkan bahwa status gizi remaja putri di Desa Brajan Mojosongo Boyolali tersebut rata - rata tergolong normal meskipun ada beberapa remaja putri yang mempunyai status gizi dalam kategori kurang dan lebih. Status gizi yang bervariasi pada remaja putri tersebut dapat terjadi karena kebiasaan yang dilakukan remaja putri dalam pemenuhan kebutuhan nutrisinya juga berbeda-beda dan kesenangan remaja putri mengkonsumsi makanan tertentu juga berbedabeda.

Menurut Tarwoto, et al. (2012), dibandingkan segmen usia yang lain, diet yang tidak adekuat adalah masalah yang paling umum dialami oleh remaja putri. Gizi yang tidak adekuat akan menimbulkan masalah kesehatan yang mengikuti sepanjang kehidupan. Kekurangan gizi selama remaja dapat disebabkan oleh bermacam-macam faktor, termasuk emosi yang tidak stabil, keinginan untuk menjadi kurus yang tidak tepat, dan ketidakstabilan dalam gaya hidup dan lingkungan sosial secara umum.

2. Usia Menarche

Dari hasil tabel usia menarche dapat dicermati bahwa persentase usia menarche paling banyak dialami responden saat 
berusia 11-13 tahun dengan jumlah 17 remaja putri $(81,0 \%)$, sedangkan usia menarche yang paling sedikit dialami remaja putri adalah usia 8-10 tahun terdapat 1 responden $(4,8 \%)$. Hal tersebut dapat terjadi karena dipengaruhi oleh faktor internal dan eksternal. Bila dijabarkan dari faktor internal usia menarche bisa dipengaruhi oleh status gizi, keturunan dan kesehatan umum dari tiap remaja putri yang terbukti mengalami menarche pada usia yang berbeda-beda, dalam penelitian ini yang terbanyak adalah usia antara 11-13 tahun, akan tetapi ada pula remaja putri yang baru mengalami menarche di usia 14-16 tahun bahkan di usia 8-10 tahun. Sedangkan faktor eksternal bisa dipengaruhi oleh kebiasaan dari remaja putri yang sudah terpapar oleh lingkungan di sekitarnya seperti seringnya mendengar atau melihat tayangan film-film tentang seksualitas.

Uraian di atas juga selaras dengan teori yang diungkapkan oleh Hinchliff (1999) sebagaimana dikutip oleh Sukarni dan Wahyu (2013), menarche adalah periode menstruasi yang pertama terjadi pada masa pubertas seorang wanita. Sedangkan menurut Pearce (1999) sebagaimana dikutip oleh Sukarni dan Wahyu (2013), menarche diartikan sebagai permulaan menstruasi pada seorang gadis pada masa pubertas, yang biasanya muncul pada usia 11 sampai 14 tahun. Menarche merupakan menstruasi pertama yang biasa terjadi dalam rentang usia 10-16 tahun atau pada masa awal remaja di tengah masa pubertas sebelum memasuki masa reproduksi.
3. Hubungan Status Gizi dengan Usia Menarche

Dari hasil penelitian Hubungan Status Gizi dengan Usia Menarche diperoleh hasil uji dengan Chi-Square program SPSS versi 16.0 dengan $\alpha=5 \%$ (0.05) diperoleh $p$ sebesar 0,653 sehingga nilai $\mathrm{p}>0.05$, yang berarti $\mathrm{Ho}$ diterima dan $\mathrm{H}_{\mathrm{a}}$ ditolak, sehingga dapat ditarik kesimpulan bahwa tidak ada hubungan antara status gizi dengan usia menarche pada remaja putri di Desa Brajan Mojosongo Boyolali.

$\begin{array}{lrr}\text { Berdasarkan hasil penelitian } \\ \text { remaja putri di Desa } & \text { Brajan } \\ \text { Mojosongo } & \text { Boyolali } & \text { usia }\end{array}$ menarche tidak berhubungan dengan status gizi, hal ini bisa terjadi karena faktor yang mempengaruhi usia menarche tidak hanya status gizi, akan tetapi ada faktor lainnya seperti keturunan, kesehatan umum, sosial, ekonomi dan faktor eksternal juga bisa mempengaruhi kapan terjadinya menarche pada usia remaja putri. Seperti telah diuraikan di atas faktor keturunan merupakan salah satu faktor yang terjadi pada remaja putri yang akan mengalami menarche, hal ini bisa dilihat dari riwayat terjadinya menarche di keluarga remaja putri tersebut misalnya dengan menanyakan usia ibu responden saat mengalami menarche seperti yang tertera dalam tabel distribusi responden berdasarkan keturunan diperoleh data ibu remaja putri yang mengalami menarche di usia 8-10 tahun sebanyak 2 ibu (9,52\%) dan kelompok usia terbanyak adalah 14-16 tahun berjumlah 10 ibu $(47,6 \%)$. Hasil tersebut dapat disimpulkan sebagian besar ibu dari responden mengalami menarche terlambat. 
Bila dilihat dari status kesehatan maka perlu diobservasi mulai dari dilahirkan sampai usia remaja apakah pernah mengalami status kesehatan yang perlu pengawasan secara berkala seperti menderita penyakit tertentu misalkan anemia. Adapun data yang diperoleh seperti tercantum dalam tabel distribusi responden berdasarkan status kesehatan dapat diinformasikan responden yang tidak pernah sakit sebanyak 18 remaja putri $(85,7 \%)$ dan yang pernah mengalami sakit ringan berjumlah 3 remaja putri (14,2\%). Dapat disimpulkan hampir semua remaja putri jarang mengalami sakit.

Faktor berikutnya adalah dari faktor sosial dan status ekonomi ada kemungkinan remaja putri yang berada dalam lingkungan keluarga dengan status sosial dan ekonomi di bawah rata-rata akan mengalami status gizi dalam kategori status gizi kurang sehingga akan mengalami keterlambatan menarche. Hal ini didukung oleh data yang tercantum dalam tabel distribusi responden berdasarkan penghasilan orang tua dimana orang tua responden yang memiliki penghasilan $>$ dari 1 juta terdapat 1 keluarga $(4,7)$ dan penghasilan terbanyak adalah 1-3 juta terdapat 12 keluarga $(57,1)$. Sehingga dapat disimpulkan sebagian besar status sosial dan ekonomi atau penghasilan orang tua responden adalah menengah ke bawah. Hal ini juga sebanding dengan pekerjaan orang tua responden yang terbanyak adalah petani seperti tertera dalam tabel distribusi responden berdasarkan pekerjaan orang tua terdapat 13 orang tua $(61,9 \%)$. Sedangkan bila dilihat dari faktor eksternal menstruasi dini juga datang dari rangsangan audio visual, baik berasal dari percakapan maupun tontonan dari film-film atau internet berlabel dewasa, vulgar, atau mengumbar sensualitas. Rangsangan dari telinga dan mata tersebut kemudian merangsang sistem reproduksi dan genital untuk lebih cepat matang seperti tercantum dalam tabel distribusi responden berdasarkan audio visual diperoleh data responden yang sering melihat tayangan audio visual sebanyak 6 responden $(28,5 \%)$ dan yang tidak pernah melihat sebanyak 14 responden $(66,6 \%)$. Sehingga dapat ditarik kesimpulan sebagian besar responden tidak melihat tayangan audio visual sensualitas. Selain itu dalam penelitian ini waktu yang dilakukan untuk pengambilan data responden terlalu singkat dan sempitnya wilayah penelitian juga berdampak pada hasil dari penelitian sehingga didapatkan hasil tidak ada hubungan antara status gizi dengan usia menarche.

Dari semua paparan faktor yang bisa mempengaruhi terjadinya usia menarche di atas bisa dipakai sebagai penjelasan berdasarkan hasil kajian data univariat dari responden untuk memperkuat bahwa hasil dari penelitian ini adalah tidak ada hubungan antara status gizi dengan usia menarche dikarenakan status gizi bukan satu-satunya faktor yang berhubungan dengan usia menarche dari remaja putri melainkan ada faktor lain yang bisa memicu terjadinya menarche pada usia remaja.

\section{KESIMPULAN}

Dari hasil penelitian didapatkan hasil $p=0,653$, sehingga $p>0,05$ yang 
berarti $\mathrm{Ha}$ ditolak dan $\mathrm{H}_{\circ}$ diterima, sehingga dapat ditarik kesimpulan bahwa tidak ada hubungan antara status gizi dengan usia menarche pada remaja putri di Desa Brajan Mojosongo Boyolali.

\section{SARAN}

Hasil penelitian ini diharapkan dapat dipakai sebagai bahan pertimbangan untuk peneliti selanjutnya agar waktu yang digunakan untuk penelitian lebih lama misalnya satu tahun dan wilayah untuk penelitian lebih luas lagi misalnya satu wilayah kecamatan sehingga jumlah responden yang didapatkan kemungkinan akan lebih banyak. Diharapkan penelitian ini bisa digunakan sebagai dasar untuk melakukan penelitian yang sama yaitu hubungan antara status gizi dengan usia menarche.

\section{DAFTAR PUSTAKA}

Fauziyah, Yulia. Infertilitas dan Gangguan Alat Reproduksi Wanita. Yogyakarta: Nuha Medika, 2012.

Hidayat, A. Aziz Aimul. Riset Keperawatan dan Teknik Penulisan IImiah. Jakarta: Salemba Medika, 2008.

. Metode Penelitian Keperawatan dan Teknik Analisis Data. Jakarta: Salemba Medika, 2009.

Kusmiran, Eny. Kesehatan Reproduksi Remaja dan Wanita. Jakarta: Salemba Medika, 2012.

Lestari, Novita. Tips Praktis Mengetahui Masa Subur. Yogyakarta: Katahati, 2011.

Proverawati, Atikah dan Erna Kusuma Wati. IImu Gizi untuk Keperawatan dan
Gizi

Kesehatan.

Yogyakarta: Nuha Medika, 2011.

Sukarni, Icemi dan Wahyu. P. Buku Ajar Keperawatan Maternitas. Yogyakarta: Nuha Medika, 2013.

Suyanto. Metode dan Aplikasi Penelitian Keperawatan. Yogyakarta: Nuha Medika, 2011.

Tarwoto, et al. Kesehatan Remaja: Problem dan Solusinya. Jakarta: Salemba Medika, 2012.

Tarwoto dan Wartonah. Kebutuhan Dasar Manusia dan Proses Keperawatan ed. 4. Jakarta: Salemba Medika, 2011.

Wiknjosastro, Hanifa, Abdul Bari Saifuddin, dan Trijatmo Rachimhadhi, ed. IImu Kandungan. Edisi II. Jakarta: Yayasan Bina Pustaka Sarwono Prawirohardjo, 2005.

Sylvia V. Hubungan Status Gizi dengan Usia Menarche pada Remaja Putri di SMP Negeri 22 Bandar Lampung. 2012.

Badriyah dan Sulastri. Pengaruh Status Gizi Terhadap Terjadinya Menarche pada Siswi Kelas VIII SMP Muhammadiyah 5 Pucang Surabaya. 2011.

\footnotetext{
1 Dosen AKPER Panti Kosala Surakarta

2 Mahasiswa AKPER Panti Kosala Surakarta

3 Mahasiswa AKPER Panti Kosala Surakarta
} 